\section{Which groups fight? Customary institutions and communal conflicts in Africa}

\section{Tore Wig}

Peace Research Institute Oslo (PRIO)

\section{Daniela Kromrey}

Department of Politics and Public Administration, University of Konstanz
Journal of Peace Research 2018, Vol. 55(4) 415-429

(C) The Author(s) 2018 Reprints and permission: sagepub.co.uk/journalsPermissions.nav DOI: $10.1177 / 0022343317740416$ journals.sagepub.com/home/jpr

@SAGE

\begin{abstract}
Why are some ethnic groups embroiled in communal conflicts while others are comparably peaceful? We explore the group-specific correlates of communal conflicts in Africa by utilizing a novel dataset combining ethnographic information on group characteristics with conflict data. Specifically, we investigate whether features of the customary political institutions of ethnic groups matter for their communal-conflict involvement. We show how institutional explanations for conflict, developed to explain state-based wars, can be successfully applied to the customary institutions of ethnic groups. We argue that customary institutions can pacify through facilitating credible nonviolent bargaining. Studying 143 ethnic groups, we provide large- $\mathrm{N}$ evidence for such an 'ethnic civil peace', showing that groups with a higher number of formalized customary institutions, like houses of chiefs, courts and legislatures, are less prone to communal conflict, both internally and with other groups. We also find some evidence, although slightly weaker, that groups with more inclusive or 'democratic' customary institutions are less prone to communal conflicts.
\end{abstract}

\title{
Keywords
}

communal conflict, customary institutions, ethnic conflict

\section{Introduction}

A large proportion of modern conflicts are between ethnic groups that are fighting each other rather than governments. A contemporary example is found in South Sudan, where violence between the two most populous groups, the Dinka and the Nuer, is threatening to tear the country apart. These two ethnic groups have been rivals, on and off for more than a century, primarily fighting over agricultural land. In the 1989-2013 period, more than 49,000 people were killed in these kinds of conflicts in Africa, which is the continent most ravaged by such 'communal' violence (Sundberg et al., 2012). As a consequence, several studies have investigated the drivers of communal conflicts, focusing on country-level (Eck, 2014) or geographic correlates (Fjelde \& von Uexkull, 2012). However, why some groups are more likely to be involved in violence, and why some groups experience internal communal conflict between its subgroups largely remains unexplored. Consequently, the current state of research has no answer to the fundamental question: Which groups fight?

We believe that an answer can be found in the characteristics of customary institutions of ethnic groups. Many ethnic groups in developing countries, and almost all in Africa, still organize in traditional political systems affecting their behaviour (e.g. Englebert, 2000; Michalopoulos \& Papaioannou, 2013; Logan, 2013). While these customary systems are often legally integrated in states, we believe their distinct character as local institutions organizing ethnic groups warrants a study of their independent impact on conflict. The continued importance of customary systems in Africa is evident in comparative work (e.g. Herbst, 2000; Englebert, 2000), and in a handful of studies showing their causal effects on development (Gennaioli \& Rainer, 2007; Michalopoulos \& Papaioannou, 2013).

Corresponding author: torewig@prio.org 
Some recent studies of civil conflict incorporate this focus, but have either dealt with the national-level impacts of customary rule (Eck, 2014) or emphasized the historical legacies of pre-colonial institutions (Wig, 2016; DepetrisChauvin, 2015).

This study expands this research programme to cover how contemporary customary institutions structure the conflict behavior of ethnic groups. Drawing on a novel dataset documenting the contemporary customary institutions and communal-conflict involvement of 143 ethnic groups in Africa, we present evidence indicating that how groups are organized in customary institutions matters for their involvement in communal conflicts. Since customary institutions in many ways resemble the political institutions of states, we draw on institutional explanations for war between and within states to explain the conflict activity of ethnic groups and their institutions. Crucially, we investigate the relevance of two quite distinct dimensions of customary institutions: their degree of formal institutionalization, and their degree of inclusiveness. While these two dimensions are distinct, they play central theoretical roles in research on institutions and state-based conflict, and we therefore singled them out for this study. We believe that increasing formal institutionalization and inclusiveness should contribute to conflict reduction, because they facilitate conflict-mediation tasks normally performed by the state in areas that are often beyond its reach.

Overall, our findings indicate that customary institutions matter. First, we find quite robust evidence that the presence and extent of formalized customary institutions, like legislatures, courts, chiefs, etc., does indeed pacify groups. Second, we find some, but much weaker, support for a negative relationship between inclusive political structures and conflict. While we cannot fully exclude that reverse causality or some omitted factor is behind these results, we believe this is an important first step in investigating the impact of customary institutions on communal conflict. Our findings speak to current research on customary systems (e.g. Eck, 2014) and contribute to the institutionalist literature on inter- and intrastate conflict (for an overview, see e.g. Hegre, 2014) by showing how explanations highlighting the role of the political institutional attributes of states can be applied fruitfully to the institutions and conflict behaviour of ethnic groups.

\section{Background}

Although ethnic groups can organize in various ways, through parties, rebel groups or religious organizations, we specifically focus on customary institutions. Customary institutions are here considered as traditional political systems that organize ethnic groups with roots in precolonial political structures. These manifest in customary legislatures, chieftaincies and courts that continue to structure ethnic politics in Africa. Recent work highlights that there is no easy classification of customary institutions as complements, competitors or integrated in the institutional complex of the state. In some respects, they are cooperative agents of the state (Boone, 2003, 2014), while in others, they serve important governance roles where states are absent (Herbst, 2000). They can also be seen as competing with the state (Eck, 2014; Wig, 2016).

African states have played a prominent part in shaping the political role of customary institutions. First, while customary institutions are often deeply rooted in precolonial history, they have also been described as 'neotraditional' in the sense that they were maintained by colonial, and post-colonial African governments (e.g. Mamdani, 1996; Ranger, 2012), implying that many have been treated favourably by central states. Second, the strength of customary institutions in several African countries is partly a product of their interaction with central governments. For example, customary authorities often serve the state as local power brokers (Boone, 2003). On this perspective, it can even be argued that customary institutions are part of a system of 'mixed government' (Sklar, 1993). This makes it hard to draw a sharp distinction between contemporary states and customary institutions.

These nuances, however, do not diminish the fact that these institutions exist and continue to structure the interactions of African ethnic groups. Customary authorities have a strong local presence, with institutional manifestations such as customary courts and councils of elders, and they are of great importance for the ethnic groups identifying with them (Logan, 2013).

A large number of African ethnic groups currently relate to such systems; some have formalized state-like institutions, with legislatures, courts and kings, while others organize in more informal structures. An example of the former is the Ashanti in Ghana, which still have a king, a council of elders and customary courts. An example of the latter are groups such as the San in Namibia, which have no such structures. In short, while African states have clearly been instrumental to the operation and status of customary institutions, their very institutional reality and local presence should warrant a study of their effects on the ethnic groups they organize. We study this for the outcome of communal conflict 
specifically, focusing on two institutional dimensions: the degree of formal institutionalization and the level of inclusiveness.

In doing so, we will not be the first to study customary institutions and communal conflict. For example, drawing on historical data on varying degrees of precolonial centralization, Wig (2016) finds that historically centralized pre-colonial institutions lower the risk of civil war. A critical contribution, more directly in contact with ours, is Eck (2014), who argues that the nationallevel presence of customary institutions creates competing jurisdictions between national legal systems and customary ones, increasing conflict risk. We take issue with this argument, and identify several nuances. First, Eck (2014) underemphasizes that customary institutions often are substitutes for national institutions where these are already weak or almost non-existent, meaning that the alternative to customary institutions in many cases is no governance at all. Second, although Eck finds robust correlations between national customary legal frameworks and communal conflict, a more direct test of Eck's argument - which Eck is aware of (2014: 446) would investigate if groups and regions with such customary legal systems experience more communal conflict. We conduct precisely such a test, providing evidence in discord with her expectation.

By building on the analogy between the customary institutions of ethnic groups and those of states, our study also speaks to the voluminous literature on state-building and violence. If one is willing to concede the noted analogy, two discussions from the state-building literature stand out as relevant. First, as scholars such as Tilly (1992, 1985) and Elias (1978) have documented, the rise of states severely reduced violence within societies. We believe our investigation contributes to this discussion by looking at how state-like institutions organizing ethnic groups can contribute to similar processes within ethnic groups. Our argument also speaks to the general discussion on state formation and interstate war (Tilly, 1992, 1985).

Our working conception of ethnic groups draws on Cederman et al. (2013: 23), who follow Weber in defining them as 'cultural communities based on a common belief in putative descent'. We restrict our focus to ethnic groups that are politically relevant in the Ethnic Power Relations (EPR) dataset (Cederman et al., 2010) to ensure that the groups we study have a sufficient level of contemporary 'groupness', in the sense that their members actually identify with them, and that they are, as Posner (2004: 853, emphasis in original) argues, the groups 'that are actually doing the competition over policy, not the ones that an ethnographer happens to identify as representing distinct cultural units'. ${ }^{1}$ Furthermore, we consider ethnic groups as potentially consisting of smaller groups (subgroups) with shared bonds to the ethnic groups. These can be organized geographically or around some other identity marker, for example a common tribal identity. An example of an ethnic group that can be broken down into subgroups is the Ovambo in Namibia, which - in addition to being a distinct ethnic group - breaks down into eight separate kingdoms. The Ashanti ethnic group in Ghana is another example, encompassing several smaller tribes.

We define communal conflicts as violent confrontations between non-state actors where the cleavages largely fall along ethnic or tribal lines. ${ }^{2}$ Within this category, we make a rough distinction between two kinds of communal conflict: conflicts between ethnic groups (intercommunal conflict), and conflicts within them (intracommunal conflict). Conflicts between ethnic groups are exemplified by recent Dinka-Nuer conflicts in South Sudan, which occur between two distinct ethnic communities. Conflicts within ethnic groups also occur frequently and are exemplified by conflicts between rival Karimojong tribes in Uganda, where the warring tribes are part of the larger Karimajong ethnic group. Distinctions between ethnic groups and subgroups are fuzzy, making it hard to distinguish between intracommunal and intercommunal conflicts.

\section{Institutional explanations for war applied to customary institutions}

There is no conventional theory of wars within and between customary systems. Fortunately, these customary political systems are often the successors to protostates and kingdoms, meaning that they share a number of state-like features that are linked to state-based wars. This makes them well suited for testing state-based institutional explanations for war at the group level. Since theories about how the institutions of a state impact on its behaviour - like the democratic peace - fundamentally are theories about the institutions of an organization

\footnotetext{
${ }^{1}$ This could induce selection bias. If groups-traits condition selection into the 'politically relevant' category, results will be biased. However, the threshold for being considered politically relevant, which is to have at least one political organization nationally, is very low, which should moderate selection bias. Furthermore, validity tests with politically irrelevant groups covered by the pre-test of the survey uncovered no strong differences between the two samples.

2 The definition is restricted to violent conflicts since nonviolent conflict is hard to code reliably across cases, resulting in little data on nonviolent communal conflict.
} 
and its conflict behaviour, testing these theories on nonstate organizations that are similar in important respects is a crucial form of theory validation (King et al., 1994).

In the following, we link group-specific institutional characteristics to the risk of conflict, focusing on the presence and extent of formal customary institutions and political inclusiveness.

\section{Formalized customary institutions}

Some groups have formalized customary institutions. We conceive of formal institutions as institutions characterized by explicit and known rules, but not necessarily written rules in line with, for example, North (1990). Formal customary institutions are instantiated in concrete entities such as tribal courts, councils of elders, or customary legislatures. Together, they constitute the structures of political authority of the ethnic group and create a clear loci of political authority. Some groups are without such institutions and organize in less formal ways without explicit and authoritative structures. Groups with formal customary institutions are often the descendants of pre-colonial empires, statelets and kingdoms and organize in the remnants of these polities, while groups without them commonly organize along kinship lines and age-sets, or are segmented without any central authority. Examples of groups in the first category are Buganda, Ashanti and the Zulu kingdom, while some examples of groups with fewer such formal arrangements are the San in Namibia and the Berbers in Algeria. ${ }^{3}$

To relate these institutions to communal conflict we draw on a central insight in bargaining theory (Fearon, 1995), which is that many conflicts erupt because of a failure to reach agreements that would have left both parties better off than in conflict, since conflict is absolutely costly. Bargaining failure primarily results from commitment problems or uncertainty relating to private information. In this general scheme, we assume that groups face bargaining problems at two levels: in relation to other groups (inter group interactions) and at the level within the group, where subgroups of a larger ethnic group can experience bargaining problems.

Building on this, we expect formal customary institutions to pacify groups by reducing uncertainty and

\footnotetext{
${ }^{3}$ It is hard to separate formal from informal institutions, especially in weak states. In the African context, informal institutions can often serve similar functions as formal ones (Meagher, 2007). We nevertheless believe the formal-informal distinction is valuable for our purposes, since it identifies groups with quite tangible formal structures such as, for example, legislatures and courts.
}

increasing the scope for credible outside commitments vis-à-vis other groups, and by facilitating more credible and legitimate internal mediation between subgroups of the same ethnic group. Below, we discuss each of these mechanisms.

Outside commitments. We argue that a group with formal state-like customary institutions should generate less external uncertainty regarding its future actions, reducing commitment problems that might prevent credible bargaining with other groups. To see this, consider a group $i$, with a set of formal authoritative institutions. We argue that group $i$ should encounter less uncertainty from outside groups regarding its future behaviour. This is because formal institutions create continuity. When $i$ has a set of formal institutions that prescribe who has authority in $i$, how decisions are to be reached, and how promises are kept, it is easier for outside actors to estimate the future behaviour of $i$ than when there are no such formal institutions.

Consider the example of spoilers. The potential for spoilers will often exacerbate the commitment problems increasing the risk of conflict (Cunningham, 2006, 2013). It is, for example, likely that a fragmented group with no formal authority such as a king or a legislature has a higher potential for spoiler dynamics than a group like the Ashanti, which has a king and a formal legislature putting constraints on the number of potential spoilers to an agreement. In this way, having formalized institutions representing the polity creates a more unified and permanent organization, making it easier to bargain with outside actors.

Having a set of formal institutions should also be expected to increase the room for 'hand-tying' in the face of commitment problems (Fearon, 1997). Hand-tying occurs when actors can impose visible ex-ante costs on themselves if they violate an agreement ex-post. A group with a set of formal institutions can impose such costs through linking promises to institutional provisions that if violated would invalidate the institution itself. For example, an agreement between two groups, $i$ and $j$, that is ratified by their customary courts, or their council of elders, would be more costly for both to violate than an agreement with no such institutional trappings. It would make it harder to violate because the ruling would need to be overturned through a formal process, but also because a violation would reduce the credibility of the institution itself, which should be a cost to the group in all circumstances. Accordingly, having formal customary institutions reduces uncertainty and imposes selfbinding constraints, making it easier for such groups to credibly commit to bargains that avoid war. 
There is some indirect empirical evidence that groups with formal customary institutions are seen as more credible bargaining partners by outside actors. For example, Baldwin (2014) argues that African leaders have devolved power over land allocation to groups with formal customary institutions because these groups can more credibly commit to getting their members to vote for said leaders, as they have clear authority structures. Accordingly, more acephalous groups with less formal authority structures have less sway over their constituents and can not be trusted to 'deliver the vote'. Baldwin presents large-N evidence for this claim in a study of 180 African regions. That strong customary institutions often are seen as credible bargaining partners by African states is also evident in the fact that African states rely on customary authorities for local conflict resolution (e.g. Beyene, 2009).

In-group mediation. Formal customary institutions should also reduce the prospect of conflicts between subgroups from the same ethnic groups. Having an overarching formal institutional structure, like a traditional kingdom, should make it easier for subgroups from the same ethnic group to settle their conflicts by relying on this common authority structure. Institutions such as tribal courts, legislatures and paramount chiefs can both facilitate mediation between the subgroups and contribute to credible enforcement of agreements. An agreement that is guaranteed through formal customary institutions will have greater credibility than one that is without such underpinnings. This credibility will sometimes rest on legitimacy. Indeed, formal customary authorities such as chiefs have a great deal of legitimacy across Africa (Logan, 2013). In other cases, it will hinge on the capacity that formalized customary authorities have for physical enforcement. In some areas, customary authorities with formal institutions will be backed by central governments in support of 'neo-traditional' local governance, and will have greater enforcement capacities as a result.

The role of formal customary institutions in policing within-group conflicts is evident in South Africa, where traditional chiefs, and notably the Zulu king, have been involved in conflict mediation, and where disputes over issues with high conflict potential, like grazing rights and land allocation, have been adjudicated by traditional courts (e.g. Choudree, 1999). Similar examples can be found throughout the continent in countries such as Ethiopia (Beyene, 2009), Sierra Leone (Sawyer, 2008) and Ghana (Ubink, 2008). Customary courts are particularly salient in conflict mediation and have been labelled 'traditional cures for modern conflicts'
(Zartman, 2000). Hence we propose that these courts reduce communal conflicts by providing arenas for credible adjudication of disputes.

The general direction of these arguments suggests a pacifying effect of having formal customary institutions on both inter- and intracommunal conflict. Formalized customary institutions should reduce commitment problems and uncertainty in relation to other groups, as well as make intragroup bargaining and adjudication of disputes easier. This yields:

Hypothesis 1: Groups with formal customary institutions are less likely to be involved in communal conflicts than other groups.

Hypothesis 1 is also consistent with an alternative explanation, namely that these groups are more often supported by the state and thus less likely to be involved in conflicts as a result. As described by Fjelde \& Østby (2014), communal conflicts are often sparked by governments favouring one group over others. Furthermore, as Elfversson (2015) demonstrates, states select which communal conflicts to manage strategically, often choosing to intervene on the behalf of supporting groups and against opposing groups. As mentioned above, groups with customary institutions are often favoured by central governments. This is described in the literature on their nature as 'neo-traditional' (Mamdani, 1996), and studies of the role(s) of customary authorities as local power brokers on behalf of governments (Boone, 2003, 2014). According to this perspective, we would expect governments to intervene to mediate communal conflicts involving groups with highly institutionalized customary systems. To account for this possibility, we let it inform our choice of controls and robustness tests.

\section{Inclusiveness}

The inclusiveness of decisionmaking structures is a salient dimension. Crucially, it probably matters how many of the members of the group get to decide on who the leadership shall be. We can think of this as the size of the 'selectorate' of the group, a concept which has figured prominently in one of the most popular accounts of the democratic peace (e.g. Bueno de Mesquita et al., 1999). In our context, the selectorate refers to the members of the given ethnic group that are eligible to have a say in who shall constitute the leaders of their groups' customary institutions. Some groups hold community-wide elections for the office of chief or king, with high openness of participation, while others select their leaders through processes with low public participation, like dynastic succession or 
election by an elite council. An example of a group with a small selectorate is Buganda. Here the king - the Kabaka - is 'elected from among the Princes of the Drum, that is, men whose father or father's father had been a Kabaka. The choice was made by the Katikkiro (prime minister) who survived from the previous reign, in consultation with other senior chiefs' (Southwold, 1965: 90).

Some groups have a larger selectorate ensured through the mechanism of popular elections. Hutchinson describes elections for executive chiefs among the Jikani Nuer in Sudan, highlighting many similarities with elections in non-customary political systems. All taxpaying males over 30 years of age could vote (Hutchinson, 1996: 273), and elections were intensely contested. Other groups have larger selectorates that are brought about by some other mechanism than an election. For example, Marshall (1965) describes how the headmen of the Kung are chosen through hereditary succession, but if a headman displeases his constituents, they will turn to someone else for leadership, akin to a parliamentary veto (Marshall, 1965: 267-268). We argue that selectorate size should matter for conflicts with other groups, either through affecting group preferences for conflict or by affecting audience costs, and that it will affect conflict within groups, through creating fewer within-group grievances.

Inter-group interactions. Selectorate theory (Bueno de Mesquita et al., 2003) proposes that leaders in countries with large selectorates (democracies) will only pick fights they anticipate winning because their risk of deposition is higher if they lose. Consequently, when two democracies have a dispute, they will reach an agreement rather than fight since the side with the highest probability of losing will back down. This is a dyadic explanation, leading to the expectation that states with large selectorates will not fight each other. Applied to ethnic groups, this leads us to expect that groups with larger selectorates should be less likely to fight other groups with similar institutions.

Another explanation for the democratic peace, that in contrast to selectorate theory yields a monadic expectation, is the audience cost explanation (Fearon, 1994). On this account, leaders with large selectorates can signal resolve more credibly, because they face a high risk of deposition if they back down on a promise or threat. In this way, democratic governments are less capable of bluffing, which increases their capacity for informative signalling that can avoid costly conflicts. The audiencecost explanation applied to groups implies that groups with large selectorates (for their customary institutions) should be more peaceful overall.

Within-group interactions. Large selectorates should also be expected to reduce the amount of intracommunal conflict since the likelihood that some subgroups will be politically excluded from affecting decisions in the customary institutions of the ethnic group will be much smaller when the selectorate is large and political institutions are inclusive. According to this argument, inclusive institutions should reduce within-group grievances. This is analogous to arguments relating democracy to civil peace through political inclusion (Hegre et al., 2001). Another potential mechanism linking inclusive customary institutions to peace is that leaders can be held more accountable in groups with inclusive institutions, incentivizing them to provide public goods such as conflict mediation. These arguments yield the following:

Hypothesis 2: Ethnic groups with customary institutions with larger selectorates are less likely to be involved in communal conflicts than other groups.

\section{Data}

Unit of analysis

Our research design requires data on ethnic group participation in communal conflicts and relevant characteristics of ethnic groups. We use the Ethnic Power Relations (EPR) dataset as a template (Cederman et al., 2010), and take individual EPR groups as units of analysis. EPR version 1.0 (Hunziker, 2011) contains information on 255 politically relevant ethnic groups in Africa, 244 of which were active in the 1989-2013 period, which is the temporal scope of our analysis. ${ }^{4}$

We proceed to match four sources of information to EPR: data on communal conflict and data on contemporary customary institutions from Kromrey (2016), as well as data on a wide range of group characteristics recorded in ethnographic studies from the early colonial period from the ethnographic atlas (Murdock, 1967). We also use geographic data on the climatic and physical environments of these groups; most these data are taken from the PRIO-GRID database (Tollefsen et al., 2012).

\footnotetext{
${ }^{4}$ Since our key independent variables (which come from Kromey, 2016) describe groups as of 2009 (EPR version 2.0), we use the list of EPR groups in 2009 to match data.
} 
Table I. Correlations between formal customary institutions

\begin{tabular}{lcllll}
\hline & Leg. council & Chief & House of chiefs & Court & Council of elders \\
\hline Chief & $0.34^{* * *}$ & & & & \\
House of chiefs & $0.19^{*}$ & $0.20^{*}$ & & & \\
Court & $0.30^{* * *}$ & $0.42^{* * *}$ & $0.31^{* * *}$ & & \\
Council of elders & $0.30^{* * *}$ & 0.04 & 0.07 & 0.09 & -0.01 \\
King & 0.08 & $0.25^{* *}$ & $0.33^{* * *}$ & $0.25^{* *}$ & -0.01 \\
\hline
\end{tabular}

This table shows the bivariate correlations between the different items making up the FCI index. The correlation coefficient is calculated using Pearsons $\mathrm{R} ;{ }^{*} p<0.05,{ }^{* *} p<0.01,{ }^{* * *} p<0.001$.

\section{Communal conflict}

To capture group participation in communal conflicts, we utilize the UCDP non-state conflict dataset (Eck et al., 2010), version 2.4. Communal conflict is a subset of non-state conflict, involving conflict that 'stands along lines of communal identity' and is fought between groups that 'share a common identification along ethnic, clan, religious, national or tribal lines' and are not 'permanently organized for combat, but who at times organize themselves along said lines to engage in fighting' (Petterson, 2012).

We match communal-conflict actors to corresponding ethnic groups in the EPR (Cederman et al., 2010). Matches are made either through direct one-to-one matching or through matching to subgroups of the given EPR groups. There are a total of 328 conflict actors in Africa in the communal conflict category. Because there are no listed EPR groups in Somalia (because Somalian groups organize on a clan basis and not along ethnic lines), we are not able to match communal conflicts in Somalia to EPR, which excludes a significant number of communal conflicts, and is a substantial source of missing information. In the remaining data, we have successfully matched 182 conflict actors to EPR groups. This constitutes about $70 \%$ of the communal conflicts, excluding Somalia. ${ }^{5}$

\section{Customary institutions}

Our data on the contemporary customary institutional structures of EPR groups come from the African Traditional Systems Dataset (ATSD), compiled by Kromrey (2016). This dataset takes EPR as a starting point and describes the traditional institutions of African ethnic groups that were politically active in 2009, using an expert web survey. Survey research offers a systematic, standardized approach to collect up-to-date information,

\footnotetext{
${ }^{5}$ For further description of the matching procedure and the dataset, see the Online appendix.
}

and the dataset relies on the ratings of experts with deep knowledge on customary systems. This method compares favourably with respondent surveys or non-expert coded data. For example, extant respondent surveys have insufficient overlap with the ethnic groups in existing conflict datasets, while non-expert coding (e.g. coding by generalists) would require more publicly available source material than currently exists (we discuss this further in the Online appendix). The collection of the data was done in 2014 through a web survey sent to more than 800 academic experts worldwide. The final dataset contains data on 153 (out of 207) politically relevant African EPR groups. Crucially, these data contain information on the presence and range of customary institutions, and several items tapping other aspects of these institutions, for instance whether they have inclusive and consensual decisionmaking structures or not. This enables us to measure both the extent and presence of formal customary institutions, as well as the inclusiveness of the political structures of the group (for more information on how we compiled the data, see Online appendix).

Formal customary institutions. To capture the presence and extent of formal institutions, we create a simple additive index of Formal Customary Institutions (FCI henceforth) registering the total number of such institutions that the group has, using a set of binary variables. It registers the presence of: a house of chiefs, a legislative council, a court system, a council of elders, a chief, a formal king and, finally, whether authority in the group is primarily based on traditional legitimacy (codings are described in the Online appendix).

Table I shows bivariate correlations between the different kinds of formal customary institutions. It shows that they often occur together, with some exceptions. We believe high scores on FCI capture high degrees of institutionalization. A group with institutions at many levels with paramount chiefs, a king, legislature, court and houses of chiefs and elders - has a complex institutional edifice which reflects a high degree of institutionalization. 
We construct an additive index for the sake of simplicity, and since we have no specific priors regarding which (combinations of) institutions should matter more. The assumption here is that a greater extent of formal customary institutions reflects a high degree of institutionalization and the degree to which the customary institutions of the ethnic group are similar to the political institutions of a state. However, a simple additive index has problems relating to item substitutability. Therefore, although our baseline models are estimated with $F C I$, we perform additional tests using an alternative measure. This registers the different traditional 'branches' of government that customary institutions correspond to: (a) a judiciary (customary court), (b) an executive (king or chief) and (c) a legislative council (legislature, council of elders, house of chiefs). The result is an ordinal measure FCI-branches registering the number of branches the group has $(3=$ all branches, $0=$ none). This variable captures possible substitution relations among customary institutions.

Inclusive institutions. Inclusive institutions is measured by focusing on the selectorate that chooses the leadership of the customary system. To capture this, we use a variable from the ATSD, constructed as follows. For each office that constitutes the institutions of the group (chiefs, courts, king, etc.), there are variables registering whether members of the group are able to select and remove their leaders to/ from that office. For each office, these variables register if the members of the ethnic community are involved in the selection process of their leadership'. If members are 'able to select and abolish their leadership' (Kromrey, 2016: 40), top scores are assigned. The values range from 1 to 3 where 1 means that ordinary members of the group are not involved in the selection process, while 3 means that all members of the group are (in principle) involved.

To create an aggregate measure of inclusiveness, we create Selectorate size by taking the mean score of these constituent variables, aggregated across all higher offices that the group has (as coded in ATSD Kromrey, 2016). ${ }^{6}$ We believe this proxies for the size of the selectorate for executive offices. Traditionally autocratic systems, like the old kingdoms of Buganda and Azande receive expectedly low scores on this variable (1.86 and 1.33, respectively).

\footnotetext{
${ }^{6}$ Admittedly, this variable does not capture the selectorate idea directly. To do that, we would have to have data on who is the chief 'executive' of the group and register the selectorate relating to that office specifically. Since we have no information on this, we choose the mentioned variable, which measures how inclusive leadership selection processes are.
}

\section{Controls}

We include a number of controls capturing alternative explanations. First, we include variables tapping the agricultural profile of the given group. Conflict over resources like land is a prominent category of communal conflict (Boone, 2014). For example, a well-known suggestion is implicit in the category of 'farmer-herder conflicts' (e.g. Hussein et al., 1999; Detges, 2014), suggesting that there is a conflictual relationship (over land) between livestock herders and crop farmers. To capture this, we include a variable measuring whether the group is historically reliant on pastoralism as a form of cultivation (Pastoralism henceforth), taken from the ethnographic atlas compiled by Murdock (1967) and matched to EPR groups by Wig (2016).

As noted, it is well established that colonial and postcolonial governments in Africa empowered traditional African rulers (e.g. Mamdani, 1996). If groups that are included in power are less likely to engage in communal conflicts, political exclusion would bias the results found for FCI. To investigate this we include a variable from the EPR dataset, capturing the political power-status of the group, ranging from 0 to 7 , where 0 is 'powerless' and 7 is 'monopoly', meaning that the group is in complete control of government (see Cederman et al., 2010 for details). Since this is a time-varying variable while our analysis is cross-sectional, we take the mean of this variable for the entire period (referred to as Political power status henceforth).

It might also be that groups with many formal institutions are more economically successful and/or have received a greater relative share of economic resources from central governments, meaning that less institutionalized groups are relatively deprived. As Cederman and colleagues demonstrate, horizontal (economic and political) inequalities between groups are a potent source of conflict (Cederman et al., 2011). Although this literature has mostly looked at conflicts with the state (i.e. ethnic civil wars), there is no reason why similar logics should not also apply to conflicts between groups, leading to the expectation that groups that are relatively deprived or excluded should be more prone to fight other groups. To capture this, we utilize a variable capturing how economically unequal the given group is when compared to the country average, as this is calculated by Cederman et al. (2011). Economic inequality (referred to as Lineq henceforth) could both be a confounding variable and an effect of complex customary institutions. The former would be the case if favourable resource conditions in an area affect both pre-colonial state formation and economic growth in that area (Fenske, 2014), causing omitted 
Table II. Logit model of communal conflict

\begin{tabular}{|c|c|c|c|c|c|c|c|}
\hline & \multicolumn{7}{|c|}{ Communal conflict (binary) } \\
\hline & 1.1 & 1.2 & 1.3 & 1.4 & 1.5 & $\begin{array}{c}1.6 \\
\text { Region-FE }\end{array}$ & $\begin{array}{c}1.7 \\
\text { Country-FE }\end{array}$ \\
\hline FCI & $\begin{array}{c}-0.339^{*} \\
(0.137)\end{array}$ & & $\begin{array}{c}-0.484^{* *} \\
(0.167)\end{array}$ & $\begin{array}{c}-0.405^{*} \\
(0.182)\end{array}$ & $\begin{array}{r}-0.400^{\dagger} \\
(0.221)\end{array}$ & $\begin{array}{c}-0.519^{*} \\
(0.256)\end{array}$ & $\begin{array}{r}-1.069^{\dagger} \\
(0.565)\end{array}$ \\
\hline Selectorate size & & $\begin{array}{c}-0.418 \\
(0.413)\end{array}$ & $\begin{array}{c}-0.584 \\
(0.446)\end{array}$ & $\begin{array}{c}-0.658 \\
(0.497)\end{array}$ & $\begin{array}{r}-0.955^{\dagger} \\
(0.564)\end{array}$ & $\begin{array}{r}-1.084^{\dagger} \\
(0.628)\end{array}$ & $\begin{array}{c}-0.088 \\
(1.550)\end{array}$ \\
\hline Political power status & & & & & $\begin{array}{r}-0.476^{\dagger} \\
(0.260)\end{array}$ & $\begin{array}{r}-0.747^{*} \\
(0.320)\end{array}$ & $\begin{array}{c}0.438 \\
(0.830)\end{array}$ \\
\hline Lineq & & & & & $\begin{array}{c}-1.293 \\
(2.891)\end{array}$ & $\begin{array}{c}-4.213 \\
(4.192)\end{array}$ & $\begin{array}{r}-31.386^{\dagger} \\
(17.457)\end{array}$ \\
\hline Pastoralism & & & & $\begin{array}{c}0.483^{* *} \\
(0.139)\end{array}$ & $\begin{array}{c}0.287 \\
(0.183)\end{array}$ & $\begin{array}{c}0.418 \\
(0.256)\end{array}$ & $\begin{array}{r}1.457^{\dagger} \\
(0.798)\end{array}$ \\
\hline $\mathrm{L}($ size $)$ & & & $\begin{array}{c}0.258 \\
(0.174)\end{array}$ & $\begin{array}{c}0.440^{*} \\
(0.205)\end{array}$ & $\begin{array}{c}0.445 \\
(0.272)\end{array}$ & $\begin{array}{c}0.620^{\dagger} \\
(0.323)\end{array}$ & $\begin{array}{c}1.508 \\
(0.932)\end{array}$ \\
\hline $\mathrm{L}$ (year) & & & $\begin{array}{c}2.066 \\
(1.289)\end{array}$ & $\begin{array}{c}2.545^{\dagger} \\
(1.299)\end{array}$ & $\begin{array}{c}3.669 \\
(2.294)\end{array}$ & $\begin{array}{c}5.253^{\dagger} \\
(3.059)\end{array}$ & $\begin{array}{c}-1.923 \\
(1,643.964)\end{array}$ \\
\hline $\mathrm{N}$ & 139 & 129 & 126 & 120 & 95 & 95 & 95 \\
\hline Log Likelihood & -70.422 & -69.443 & -60.381 & -51.484 & -42.276 & -38.176 & -14.338 \\
\hline AIC & 144.843 & 142.887 & 130.761 & 114.968 & 100.553 & 102.352 & 102.677 \\
\hline
\end{tabular}

${ }^{\dagger} p<0.1,{ }^{*} p<0.05,{ }^{* *} p<0.01$.

variable bias. The latter would be the case if state-like customary institutions affect growth (Michalopoulos \& Papaioannou, 2013), where inclusion of this variable would cause post-treatment bias. Since neither can be ruled out, we run models both with and without Lineq.

In our core models, we also include the log of the population size of the group $(L($ size $))$, measured using EPR, and the $\log$ of the number of years the group has been registered as politically relevant in EPR, since more years in the data increases the likelihood of experiencing conflict $(L($ year $))$. Finally, we include country- and regiondummies (separately) in several models, to capture omitted country- and region-level variables. In addition to these baseline models, we control for a range of additional variables in further robustness checks (see below).

\section{Estimation}

Our baseline models capture the log odds of a group experiencing at least one communal conflict over the period 1989-2013. We estimate:

$$
\log \left\{\frac{P\left(C_{i}\right)}{1-P\left(C_{i}\right)}\right\}=\beta_{0}+\delta X_{i}+\gamma \alpha+\varepsilon_{i}
$$

Where $C_{i}$ is communal conflict incidence for group $i$, $X$ is a vector of group variables including FCI, Selectorate size and the covariates, and $\alpha$ is a vector of country- or region-dummies. In our core analyses we go from a parsimonious to a fully specified model, entering control variables in a stepwise fashion, to assess stability.

Table II shows our baseline models, only including the core controls. We start with two parsimonious models, including Selectorate size and FCI separately (columns 1.1 and 1.2), before entering baseline controls and country- or region-dummies.

First, we investigate Hypothesis 1, stating that groups with higher levels of $F C I$ will be less prone to communal conflict. Model 1.1 shows the raw estimate for FCI with no covariates. The coefficient here is -.339 (with an SE of 0.137), indicating that the risk of experiencing at least one communal conflict drops with increases in FCI.

This pattern is strengthened in Models 1.2-1.3 where $L($ size) and $L$ (year) are added as controls, and Models 1.4 and 1.5 where we include pastoralism and the variables capturing political and economic inequality (Political power status and Lineq). Models 1.6 and 1.7 include region and country dummies, respectively. The estimate for $F C I$ is actually strengthened in the model where we include region dummies: the coefficient is larger (-.519) and more precisely estimated than in model 1.5 ( $\mathrm{SE}=$ 0.256). In Model 1.7 where we include country dummies - which is a very demanding model (37 covariates on 95 observations) - the pattern is expectedly less precise than in Model 1.6, but FCI is still negatively associated with communal conflict. This provides some support for 
H1: groups with formalized customary institutions seem less likely to be involved in communal conflict.

Turning to Hypothesis 2, which is tested here using the Selectorate size variable, we find less support. Although the sign on the Selectorate size variable is in the expected (negative) direction in all models, the coefficient is not precisely enough estimated to conclude that there is an association. However, in some models (1.51.6) Selectorate size is more precise. In spite of Selectorate size being significant in some models, the main conclusion is that the pattern for $F C I$ is not there for Selectorate size to the same degree.

Meanwhile, few of the other covariates predict communal conflict. Pastoralism is in the expected direction but not robust. Political power status is also in the expected direction and mostly significant. The Lineq coefficient goes in the opposite direction from expectations, although this is imprecisely estimated. ${ }^{7}$

The effect of $F C I$ is substantial. Figure 1 shows the simulated probability of experiencing at least one communal conflict for groups with different levels of FCI, when all other covariates are held at their median levels. This shows that increasing FCI from its minimum to its maximum value yields a decrease in the risk of experiencing at least one communal conflict over the 1989-2013 period from $42 \%$ to roughly $10 \%$ - for a group with mean values on the covariates in Model 1.5 - which represents a substantial decrease.

In addition to logit models, we run linear models, estimating the log of the number of communal conflicts experienced by a group in the time period under study. This is to investigate whether our variables matter not only for experiencing any communal conflicts, but also whether there is an impact on the number of conflicts. Results from these models can be seen in Table III. Here, $F C I$ is negatively related to conflict, and precisely estimated in most models. Coefficients range from -.342 (Model 2.3) to -.259 (Model 2.7). The coefficient is precisely estimated in most specifications: statistically significant in Models 2.1-2.4 and 2.6, but not in the model including country-FE's (2.7) nor in the model with the full set of controls but not including regiondummies.

As mentioned, a potential weakness in our design is the use of the simple additive FCI index, which does not

\footnotetext{
${ }^{7}$ Note that Political power status reverses sign in the logit models with country-dummies. This indicates that countries with lower levels of political exclusion (of ethnic groups) see less communal conflict, while excluded ethnic groups are no more likely to experience communal conflict, at least in our data.
}

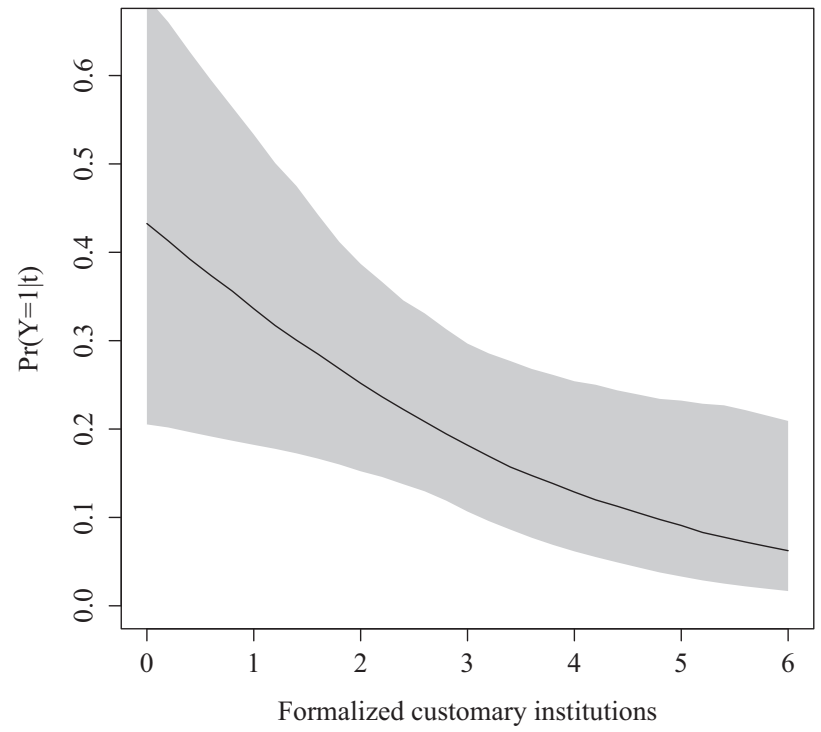

Figure 1. Simulated probability of communal conflict, 19892012

The simulation is based on Model 1.5 in Table II. All covariates are held at mean values.

capture potential substitution effects. To engage this problem, we run the same tests as those performed in Table II on our FCI-branches measure, described above. The results from this analysis, presented in the Online appendix, show that our results are highly robust to this alternative.

\section{Controlling for alternative pathways}

In addition to the alternative explanations justifying the controls in the baseline models, we here run some tests with additional controls. The controls listed here will be given more detailed operationalizations in the Online appendix.

First, a number of variables relating to the physical climate of the groups in question might correlate with the presence of customary institutions and with conflict. For example, rainfall patterns dispose areas for conflict (Fjelde \& von Uexkull, 2012), and correlate with ecological niches that historically gave rise to pre-colonial states (Fenske, 2014). We measure this using a variable registering the average value on the SPI6 drought index in the area inhabited by the group, taken from the PRIO-GRID database (Tollefsen et al., 2012) where the area inhabited by the group is mapped using the GEOEPR data (Wucherpfennig et al., 2011). We also control for the log of the rainfall range in the area, taken from Fenske (2014). As another environmental indicator, we 
Table III. Linear models of $\log ($ communal conflicts +0.001$)$

\begin{tabular}{|c|c|c|c|c|c|c|c|}
\hline & \multicolumn{7}{|c|}{ Log number of communal conflicts } \\
\hline & 2.1 & 2.2 & 2.3 & 2.4 & 2.5 & $\begin{array}{c}2.6 \\
\text { Region-FE }\end{array}$ & $\begin{array}{c}2.7 \\
\text { Country-FE }\end{array}$ \\
\hline FCI & $\begin{array}{c}-0.315^{* *} \\
(0.117)\end{array}$ & & $\begin{array}{c}-0.342^{* *} \\
(0.120)\end{array}$ & $\begin{array}{r}-0.305^{*} \\
(0.132)\end{array}$ & $\begin{array}{c}-0.268 \\
(0.172)\end{array}$ & $\begin{array}{r}-0.291^{\dagger} \\
(0.173)\end{array}$ & $\begin{array}{r}-0.259 \\
(0.168)\end{array}$ \\
\hline Selectorate size & & $\begin{array}{r}-0.438 \\
(0.406)\end{array}$ & & $\begin{array}{c}-0.575 \\
(0.389)\end{array}$ & $\begin{array}{c}-0.677 \\
(0.462)\end{array}$ & $\begin{array}{c}-0.535 \\
(0.468)\end{array}$ & $\begin{array}{r}-0.080 \\
(0.475)\end{array}$ \\
\hline Political power status & & & & & $\begin{array}{r}-0.360^{\dagger} \\
(0.210)\end{array}$ & $\begin{array}{r}-0.518^{*} \\
(0.232)\end{array}$ & $\begin{array}{c}-0.285 \\
(0.274)\end{array}$ \\
\hline Lineq & & & & & $\begin{array}{c}-0.313 \\
(1.012)\end{array}$ & $\begin{array}{c}-0.491 \\
(1.011)\end{array}$ & $\begin{array}{r}-0.543 \\
(0.912)\end{array}$ \\
\hline Pastoralism & & & & $\begin{array}{c}0.443^{* *} \\
(0.106)\end{array}$ & $\begin{array}{c}0.422^{* *} \\
(0.158)\end{array}$ & $\begin{array}{c}0.481^{*} \\
(0.190)\end{array}$ & $\begin{array}{c}0.361^{\dagger} \\
(0.190)\end{array}$ \\
\hline $\mathrm{L}($ size $)$ & & & $\begin{array}{c}0.206 \\
(0.144)\end{array}$ & $\begin{array}{c}0.314^{*} \\
(0.147)\end{array}$ & $\begin{array}{c}0.358 \\
(0.236)\end{array}$ & $\begin{array}{c}0.468^{\dagger} \\
(0.242)\end{array}$ & $\begin{array}{c}0.638^{*} \\
(0.240)\end{array}$ \\
\hline L(year) & & & $\begin{array}{r}1.199^{\dagger} \\
(0.689)\end{array}$ & $\begin{array}{r}1.492^{*} \\
(0.685)\end{array}$ & $\begin{array}{r}1.787^{\dagger} \\
(1.009)\end{array}$ & $\begin{array}{c}2.224^{\dagger} \\
(1.223)\end{array}$ & $\begin{array}{c}-0.267 \\
(0.202)\end{array}$ \\
\hline Constant & $\begin{array}{c}-2.477^{* *} \\
(0.392)\end{array}$ & $\begin{array}{c}-2.411^{* *} \\
(0.880)\end{array}$ & $\begin{array}{r}-15.633^{\dagger} \\
(7.946)\end{array}$ & $\begin{array}{c}-18.569^{*} \\
(8.130)\end{array}$ & $\begin{array}{r}-20.291^{\dagger} \\
(12.098)\end{array}$ & & \\
\hline $\mathrm{N}$ & 139 & 129 & 139 & 120 & 95 & 95 & 95 \\
\hline $\mathrm{R}^{2}$ & 0.050 & 0.009 & 0.086 & 0.239 & 0.262 & 0.733 & 0.867 \\
\hline Adjusted $\mathrm{R}^{2}$ & 0.043 & 0.001 & 0.065 & 0.206 & 0.203 & 0.691 & 0.782 \\
\hline
\end{tabular}

${ }^{\dagger} p<0.1,{ }^{*} p<0.05,{ }^{* *} p<0.01$.

use the share of the group's settlement area that is covered by mountainous terrain, also from PRIO-GRID. We also include the log of the distance of the settlement area of the group to the border and capital, respectively, to see whether the location of the group in a country matters (see e.g. Buhaug \& Rød, 2006). Finally, it is quite plausible that groups with larger settlement areas have more conflicts, as larger territories should give rise to more property-related disputes. One might also expect that groups that historically controlled larger territories would develop more state-like institutions to control that territory, while simultaneously pacifying their subject population(s). This might yield bias if groups with high FCI settle larger areas. To capture this, we include a control registering the log of the settlement area of the group (in square kilometers), using GEO-EPR.

A second category of controls relates to the agricultural history of ethnic groups. Some groups have a history of specific kinds of agriculture, residing in climatic zones hospitable to agriculture, that probably correlates both with certain kinds of customary institutions and with conflict. We control for the degree of historical Agricultural complexity registered for the group in the Ethnographic Atlas (EA henceforth) (Murdock, 1967).
In addition to this, we employ a control registering whether the group is historically dependent on gathering for sustenance, also taken from the EA.

A third set of controls relates to cultural aspects of the groups, that might affect both their institutions and their conflict involvement. We control for whether the group is organized in a clan structure, which might be detrimental to institutional development (e.g. Fukuyama, 2011) and dispose for conflict (e.g. Boehm, 1984). We also control for whether the group was nomadic, for whether it had a hierarchical local governance structure, and for the social stratification of the group. All of these covariates are taken from the EA.

A final category of controls relates to the economic fortunes of ethnic groups. As has been shown, groups with a history of early statehood - which should be reflected in current customary institutions - experience higher levels of economic development than other groups (Michalopoulos \& Papaioannou, 2013, 2015), and absolutely poorer groups might be more disposed to conflict. We therefore include the average satellite night-light density in the settlement area of the group, taken from PRIO-GRID. These controls are included to see whether the relationship between FCI and conflict is spurious to income. 
Table IV. Logit models of communal conflict

\begin{tabular}{|c|c|c|c|c|c|}
\hline & \multicolumn{5}{|c|}{ Communal conflict (binary) } \\
\hline & Border distance & Cap. distance & Rainfall range & Drought index & Mountains \\
\hline FCI & $\begin{array}{r}-0.371^{\dagger} \\
(0.214)\end{array}$ & $\begin{array}{r}-0.365^{\dagger} \\
(0.212)\end{array}$ & $\begin{array}{r}-0.420^{\dagger} \\
(0.236)\end{array}$ & $\begin{array}{r}-0.379^{\dagger} \\
(0.215)\end{array}$ & $\begin{array}{r}-0.409^{\dagger} \\
(0.221)\end{array}$ \\
\hline $\mathrm{N}$ & 102 & 102 & 94 & 102 & 102 \\
\hline Log Likelihood & -42.490 & -41.959 & -37.377 & -41.984 & -40.597 \\
\hline \multirow[t]{3}{*}{ AIC } & 110.980 & 109.918 & 100.754 & 109.969 & 107.193 \\
\hline & \multicolumn{5}{|c|}{ Communal conflict (binary) } \\
\hline & Settlement area $\left(\mathrm{Km}^{2}\right)$ & Clan & Agriculture & Night lights & Nomad \\
\hline FCI & $\begin{array}{r}-0.441^{\dagger} \\
(0.227)\end{array}$ & $\begin{array}{r}-0.365^{\dagger} \\
(0.217)\end{array}$ & $\begin{array}{r}-0.425^{\dagger} \\
(0.235)\end{array}$ & $\begin{array}{r}-0.359^{\dagger} \\
(0.213)\end{array}$ & $\begin{array}{r}-0.373^{\dagger} \\
(0.217)\end{array}$ \\
\hline $\mathrm{N}$ & 96 & 103 & 94 & 102 & 103 \\
\hline Log Likelihood & -36.178 & -42.832 & -36.098 & -42.445 & -42.675 \\
\hline \multirow[t]{3}{*}{$\mathrm{AIC}$} & 98.357 & 111.664 & 98.197 & 110.891 & 111.350 \\
\hline & \multicolumn{5}{|c|}{ Communal conflict (binary) } \\
\hline & Gathering & Community size & Ecological diversity & Local hierarchy & Social stratification \\
\hline FCI & $\begin{array}{r}-0.359^{\dagger} \\
(0.213)\end{array}$ & $\begin{array}{r}-0.352^{\dagger} \\
(0.213)\end{array}$ & $\begin{array}{c}-0.493^{\dagger \dagger} \\
(0.239)\end{array}$ & $\begin{array}{r}-0.366^{\dagger} \\
(0.219)\end{array}$ & $\begin{array}{r}-0.372^{\dagger} \\
(0.211)\end{array}$ \\
\hline $\mathrm{N}$ & 103 & 103 & 102 & 103 & 103 \\
\hline Log Likelihood & -41.462 & -42.839 & -37.951 & -41.218 & -41.988 \\
\hline AIC & 108.924 & 111.677 & 101.901 & 108.435 & 109.976 \\
\hline
\end{tabular}

${ }^{\dagger} p<0.1,{ }^{* *} p<0.05,{ }^{* * *} p<0.01$.

All models are estimated with covariates from Model 1.6. All covariate terms are excluded from the table.

Results from models including these controls can be seen in Table IV, displaying the coefficients for FCI for models where controls are entered separately into model 1.6 in Table II (the table excludes all other coefficients, for reasons of presentation). Since there are too few degrees of freedom to enter all controls in one joint model, we enter them one by one. We only conduct this battery of tests on the FCI measure, since it was the only variable yielding robust results across the baselines. The first panel indicates that the key result for the FCI coefficient remains across various controls for the physical environment; the result is qualitatively unchanged by the inclusion of border distance, capital distance, rainfall range, the drought measure and mountains, respectively. The middle panel shows the FCI results when we include settlement area, clan structure, agriculture, night-light density and nomadism. As is clear from this panel, the FCI result remains relatively stable across these specifications, yet it is slightly weakened in the model including slavery (with only 94 observations). Finally, the bottom panel includes controls for whether the group historically practised gathering, the community size registered for the group in the EA, the ecological diversity in the settlement area of the group, hierarchical local organization, and social stratification. FCI retains size and sign in all these models.

Although the noted relationship is highly robust, there is one plausible alternative explanation we have not been able to exclude, namely reverse causality. Reverse causality would arise if groups with more formal customary institutions have these institutions because they are less conflict prone. If, for example, it is precisely those groups that have been able to solve or 'fight out' their intragroup enmities that have been able to consolidate into kingdoms or empires in pre-colonial times, it follows that these groups have these institutions because they have solved the problem of within-group conflict. Since we have no strong identification strategy, we are not able to rule this out. An issue for further research would be to probe this possibility in greater depth.

\section{Conclusion}

This article explores the role of customary institutions in communal conflicts. We argue that many politically 
relevant ethnic groups across Africa organize in customary political systems whose features shape their conflict involvement. First, we argue that groups with formal state-like customary institutions should experience fewer conflicts ceteris paribus. On this view, a group like the Buganda, with a king, a legislature and courts, should have a lower conflict risk due to the role these institutions can play in credible bargaining that can prevent internal and external conflicts.

Second, we conjectured that the inclusiveness of customary institutions should matter. A group with inclusive decisionmaking structures should experience less conflict because these structures, for example, reduce within-group fighting.

Drawing on a novel dataset covering 143 politically ethnic groups and their organization in customary institutions, we find strong support for the first of these propositions, and no robust support for the second.

Our findings challenge the claim of a conflictinducing effect of customary institutions. Contrary to the argument in Eck (2014), we show that the presence of formal customary institutions reduces conflict at the actor level. The claim that customary institutions conduce conflict overlooks that traditional rulers often serve important conflict-mediating roles in areas where national level institutions are weak. Admittedly, there is a clear tension between the country-level results in Eck (2014) and ours. The fact that Eck finds a positive association between customary law systems and communal conflict at the country level, while our results indicate the opposite at the group level, might suggest that there is something conflict-inducing about the countries that have these dual-law systems, but that does not inhere to the groups with these institutions. One possible explanation is that having strong customary authorities is endogenous to weak state capacity, which is implied if central governments empower customary authorities because of local weakness.

Our results have implications for several fields of research. First, they outline ways of incorporating ethnic group institutions into the general study of ethnic groups in conflict (e.g. Cederman et al., 2013). One potential avenue for research would be to investigate how traditional customary institutions have affected the political and economic inequalities that drive current ethnic conflicts. Second, it speaks to the literature on ethnic politics in Africa (Posner, 2005; Herbst, 2000), and especially those studies that emphasize customary institutions (Englebert, 2000; Boone, 2003, 2014), as well as the recent economic literature on pre-colonial institutions and development (e.g. Michalopoulos \&
Papaioannou, 2013). In contrast to much of the works highlighting the corrosive effects of traditional rulers on political and economic development (Mamdani, 1996), we highlight their constructive role in creating local civil peace. Third, this study relates indirectly to time-honoured questions in social science regarding the relationship between state centralization and armed conflict. For example, in line with the view that states pacify their internal populations (e.g. Tilly, 1985; Elias, 1978), we find that organizations with similar features (customary institutions) have similarly beneficial effects. Finally, and perhaps most importantly, we add to the growing literature on the factors associated with communal conflict (Fjelde \& von Uexkull, 2012; Eck, 2014; Sundberg et al., 2012), demonstrating the need to investigate the organizational and institutional structures of the actors involved. Our study highlights a variable that should be central in further research on communal conflict.

Several policy implications spring from these findings. If we are correct, the autonomous governance of local customary authorities should be considered as a good in places with a high potential for communal conflict. In fact, if customary authorities exist, governments should build up their capacities if local security is the goal. If such institutions are absent, policymakers should strengthen other local institutions that can serve similar roles when it comes to within- and between-group conflict mediation, such as local municipal and regional governments. Furthermore, our study also suggests that local customary authorities should be included in active peace processes across Africa. More broadly, formal customary institutions should be given a greater role in mediating communal conflicts, especially in weak states where the local government institutions of the state are unable to perform such tasks.

\section{Replication data}

The dataset and $\mathrm{r}$ code used for the empirical analyses in this article, as well as the Online appendix, can be found at https://www.prio.org/jpr/datasets/. The analyses were carried out using $\mathrm{R}$.

\section{Acknowledgements}

The authors thank the following for comments and suggestions: Hanne Fjelde, Lars-Erik Cederman, Håvard Hegre, Carl Henrik Knutsen, Sirianne Dahlum, participants at the 'Civil Conflict and Democratization' workshop at the University of Århus participants at the ENCORE meeting in Uppsala in 2015 and participants 
at the 'Traditional Governance and Indigenous Peoples' workshop at the University of Konstanz in 2016.

\section{Funding}

Daniela Kromrey acknowledges the support of the Friedrich Ebert Foundation.

\section{References}

Baldwin, Kate (2014) When politicians cede control of resources: Land, chiefs, and coalition-building in Africa. Comparative Politics 46(3): 253-271.

Beyene, Fekadu (2009) Property rights conflict, customary institutions and the state: The case of agro-pastoralists in Mieso district, eastern Ethiopia. Journal of Modern African Studies 47(2): 213-239.

Boehm, Christopher (1984) Blood Revenge: The Enactment and Management of Conflict in Montenegro and Other Tribal Societies. Philadelphia, PA: University of Pennsylvania Press.

Boone, Catherine (2003) Political Topographies of the African State. New York: Cambridge University Press.

Boone, Catherine (2014) Property and Political Order in Africa: Land Rights and the Structure of Politics. New York: Cambridge University Press.

Bueno de Mesquita, Bruce; James D Morrow, Randolph M Siverson \& Alastair Smith (1999) An institutional explanation of the democratic peace. American Political Science Review 93(4): 791-807.

Bueno de Mesquita, Bruce; Alistair Smith, Randolph M Siverson \& James D Morrow (2003) The Logic of Political Survival. Cambridge, MA: MIT Press.

Buhaug, Halvard \& Jan Ketil Rød (2006) Local determinants of African civil wars, 1970-2001. Political Geography 25(3): 315-335.

Cederman, Lars-Erik; Kristian Skrede Gleditsch \& Halvard Buhaug (2013) Inequality, Grievances and Civil War. New York: Cambridge University Press.

Cederman, Lars-Erik; Nils B Weidmann \& Kristian Skrede Gleditsch (2011) Horizontal inequalities and ethnonationalist civil war: A global comparison. American Political Science Review 105(3): 478-495.

Cederman, Lars-Erik; Andreas Wimmer \& Brian Min (2010) Why do ethnic groups rebel? New data and analysis. World Politics 62(1): 87-119.

Choudree, RBG (1999) Traditions of conflict resolution in South Africa. African Journal on Conflict Resolution 1(1): 9-27.

Cunningham, David E (2006) Veto players and civil war duration. American Journal of Political Science 50(4): 875-892.

Cunningham, Kathleen G (2013) Actor fragmentation and civil war bargaining: How internal divisions generate civil conflict. American Journal of Political Science 57(3): 659-672.

Depetris-Chauvin, Emilio (2015) State history and contemporary conflict: Evidence from sub-Saharan Africa.
Working paper, Instituto de Economia. Pontificia Universidad Católica de Chile.

Detges, Adrien (2014) Close-up on renewable resources and armed conflict: The spatial logic of pastoralist violence in northern Kenya. Political Geography 42: 57-65.

Eck, Kristine (2014) The law of the land: Communal conflict and legal authority. Journal of Peace Research 51(4): 441-454.

Eck, Kristine; Joakim Kreutz \& Ralph Sundberg (2010) Introducing the UCDP non-state conflict dataset. Journal of Peace Research 49(2): 351-362.

Elfversson, Emma (2015) Providing security or protecting interests? Government interventions in violent communal conflicts in Africa. Journal of Peace Research 52(6): 791-805.

Elias, Norbert (1978) The History of Manners: The Civilizing Process, Vol. 1. New York: Pantheon.

Englebert, Pierre (2000) Pre-colonial institutions and post-colonial states and economic development in tropical Africa. Political Research Quarterly 53(7): 7-36.

Fearon, James D (1994) Domestic political audiences and the escalation of international disputes. American Political Science Review 88(3): 577-592.

Fearon, James D (1995) Rationalist explanations for war. International Organization 49(3): 379-414.

Fearon, James D (1997) Signaling foreign policy interests: Tying hands versus sinking costs. Journal of Conflict Resolution 41(1): 68-90.

Fenske, James (2014) Ecology, trade, and states in pre-colonial Africa. Journal of the European Economic Association 12(3): 612-640.

Fjelde, Hanne \& Gudrun Østby (2014) Socioeconomic inequality and communal conflict: A disaggregated analysis of sub-Saharan Africa, 1990-2008. International Interactions 40(5): 737-762.

Fjelde, Hanne \& Nina von Uexkull (2012) Climate triggers: Rainfall anomalies, vulnerability and communal conflict in sub-Saharan Africa. Political Geography 31(7): 444-453.

Fukuyama, Francis (2011) The Origins of Political Order: From Prehuman Times to the French Revolution. New York: Profile.

Gennaioli, Nicola \& Ilia Rainer (2007) The modern impact of precolonial centralization in Africa. Journal of Economic Growth 12: 185-234.

Hegre, Håvard (2014) Democracy and armed conflict. Journal of Peace Research 51(2): 159-172.

Hegre, Håvard; Tanja Ellingsen, Scott Gates \& Nils Petter Gleditsch (2001) Toward a democratic civil peace? Democracy, political change, and civil war, 1816-1992. American Political Science Review 95(1): 33-48.

Herbst, Jeffrey (2000) States and Power in Africa: Comparative Lessons in Authority and Control. Princeton, NJ: Princeton University Press.

Hunziker, Phillipp (2011) Grow ${ }^{\text {up }}$ Research Front-end Documentation RFE Release 1.1. (https://icr.ethz.ch/data/ growup/RFE_Documentation_1.1.pdf). 
Hussein, Karim; James Sumberg \& David Seddon (1999) Increasing violent conflict between herders and farmers in Africa: Claims and evidence. Development Policy Review 17(4): 397-418.

Hutchinson, Sharon E (1996) Nuer Dilemmas: Coping with Money, War, and the State. Los Angeles, CA: University of California Press.

King, Gary; Robert O Keohane \& Sidney Verba (1994) Designing Social Inquiry: Scientific Inference in Qualitative Research (Kindle edition). Princeton, NJ: Princeton University Press.

Kromrey, Daniela (2016) African tradition of democracy: Assessing the democraticness of traditional political systems and their effect on democracy in Africa. PhD thesis, University of Konstanz.

Logan, Carolyn (2013) The roots of resilience: Exploring popular support for African traditional authorities. African Affairs 112(448): 353-376.

Mamdani, Mahmood (1996) Citizen and Subject: Contemporary Africa and the Legacy of Late Colonialism. Princeton, NJ: Princeton University Press.

Marshall, Lorna (1965) The !Kung bushmen of the Kalahari desert. In: James L Gibbs Jr (ed.) Peoples of Africa. New York: Holt, Rinehart \& Winston, 81-119.

Meagher, Kate (2007) Introduction: Special issue on 'Informal institutions and development in Africa'. Africa Spectrum 42(3): 405-418.

Michalopoulos, Stelios \& Elias Papaioannou (2013) Pre-colonial ethnic institutions and contemporary African development. Econometrica 81(1): 113-152.

Michalopoulos, Stelios \& Elias Papaioannou (2015) Further evidence on the link between pre-colonial political centralization and comparative economic development in Africa. Economics Letters 126: 57-62.

Murdock, George P (1967) Ethnographic atlas: A summary. Ethnology 6(2): 109-236.

North, Douglass C (1990) Institutions, Institutional Change and Economic Performance. Cambridge: Cambridge University Press.

Petterson, Theresa (2012) UCDP non-state conflict codebook, version 2.4-2012. Journal of Peace Research 49(2): 351-362.

Posner, Daniel N (2004) Measuring ethnic fractionalization in Africa. American Journal of Political Science 48(4): 849-863.

Posner, Daniel N (2005) Institutions and Ethnic Politics in Africa. New York: Cambridge University Press.

Ranger, Terence (2012) The invention of tradition in colonial Africa. In: Eric Hobsbawm \& Terence Ranger (eds) The Invention of Tradition. Cambridge: Cambridge University Press, 211-263.
Sawyer, Edward (2008) Remove or reform? A case for (restructuring) chiefdom governance in post-conflict Sierra Leone. African Affairs 107(428): 387-403.

Sklar, Richard (1993) The African frontier for political science. In: Robert H Bates, VY Mundimbe \& Jean O'Barr (eds) Africa and the Disciplines: The Contributions of Research in Africa to the Social Sciences and Humanities. Chicago, IL: The University of Chicago Press.

Southwold, Martin (1965) The ganda of Uganda. In: James L Gibbs Jr (ed.) Peoples of Africa. New York: Holt Rinehart \& Winston, 81-119.

Sundberg, Ralph; Kristine Eck \& Joakim Kreutz (2012) Introducing the UCDP non-state conflict dataset. Journal of Peace Research 49(2): 351-362.

Tilly, Charles (1985) War making and state making as organized crime. In: Peter B Evans (ed.) Bringing the State Back In. Cambridge: Cambridge University Press, 169-191.

Tilly, Charles (1992) Coercion, Capital, and European States, AD 990-1992. Oxford: Blackwell.

Tollefsen, Andreas Forø; Håvard Strand \& Halvard Buhaug (2012) PRIO-GRID: A unified spatial data structure. Journal of Peace Research 49(2): 363-374.

Ubink, Janine M (2008) In the land of the chiefs: Customary law, land conflicts and the role of the state in Peri-Urban Ghana. Unpublished PhD thesis, Leiden University.

Wig, Tore (2016) Peace from the past pre-colonial political institutions and civil wars in Africa. Journal of Peace Research 53(4): 509-524.

Wucherpfennig, Julian; Nils B Weidmann, Luc Girardin, Lars-Erik Cederman \& Andreas Wimmer (2011) Politically relevant ethnic groups across space and time: Introducing the GeoEPR dataset. Conflict Management and Peace Science 28(5): 423-437.

Zartman, I William (2000) Traditional Cures for Modern Conflicts: African Conflict 'Medicine'. London: Lynne Rienner.

TORE WIG, b. 1985, PhD in Political Science (University of Oslo, 2015); Senior Researcher at Peace Research Institute Oslo (PRIO) (2015- ) and Associated Researcher at the University of Oslo; current research interests: civil conflict, mass protest in dictatorships and regime stability.

DANIELA KROMREY, b. 1983, PhD in Politics and Public Administration (University of Konstanz, 2016); Program Director for Internationalization at the Zukunftskolleg - Institute for Advanced Study at the University of Konstanz (2016- ); current research interests: traditional political systems, democratization, legacies of freedom fighters in Africa and survey research. 